NBER WORKING PAPERS SERIES

MACROECONOMIC MODELS WITH EQUITY

AND CREDIT RATIONING

Bruce C. Greenwald
Joseph E. Stiglitz

Working Paper No. 3533

NATIONAL BUREAU OF ECONOMIC RESEARCH

1050 Massachusetts Avenue

Cambridge, MA 02138

December 1990

This paper is part of NBER's research program in Economic Fluctuations. Any opinions expressed are those of the authors and not those of the National Bureau of Economic Research. 
NBER Working Paper \#3533

December 1990

\section{MACROECONOMIC MODELS WITH EQUITY \\ AND CREDIT RATIONING}

\section{ABSTRACT}

This paper presents a simple, general equilibrium macroeconomic model incorporating financial constraints, both credit and equity rationing, as well as other informational imperfections in labor and product markets, such as efficiency wage effects. A formulation somewhat analogous to the standard IS-LM model, but not suffering from the well known defects of that model, is derived. The mechanisms by which monetary policy affects the economy are described. Dynamics, including implications for long run growth, are investigated.

Bruce C. Greenwald Room 2A-347 Bell Communications Research 435 South street Morristown, NJ 07960-1961
Joseph E. Stiglitz Department of Economics Encina Hall Stanford University stanford, CA 94305-6072 
The role played by imperfect information in business fluctuations has received increasing attention since Lucas' early work. ${ }^{1}$ However the locus of that anention has shifted from systematic misperceptions of prices (the original Lucas form of imperfect information) to the macroeconomic consequences of information related microeconomic failures. ${ }^{2}$ This paper seeks to summarize a major development of this latter literature, to integrate that development into a standard macroeconomic model and to provide a reformulation which casts additional light on the mechanism by which monetary policy affects the economy. The microeconomic failures in question occur most significanly in financial markets. In credit markets, it is by now wellestablished that lenders who are less well-informed than borrowers about the risk characteristics of the borrower's investment projects may well respond by fixing interest rates and (under cer. tain conditions) rationing credit. ${ }^{3}$ In equity markets, it is equally well established that, when potential equity issuers are better informed about their future prospects than potential equity purchasers, raising funds by issuing new equity may be a highly costly, if not prohibitively difficult, underaking. ${ }^{4}$ Briefly and crudely stated, the significant macroeconomic consequences of these financial market failures (which are essentially microeconomic in nature) include an increase in the importance of intermally generated funds in determining firm behavior - especially invest. ment behavior, a reduction in the importance of interest rates as a determinant of both borrowing and investment (and hence as a macroeconomically stabilizing variable); amplification of the output responses of firms to demand and other disturbances, the risks and cash flow consequences of which cannot be shifted either by issuing equity or by increased borrowing (leading

\footnotetext{
1 See Lucas [1979].

2 See Bermanke and Gerter [1989], Shapiro and Sugliz [1984]. Diamond [1982] and Greenwald, Suiglitz and Weiss [1984] for diverse examples from a large and growing literature.

3 See Stiglizz and Weiss [1981].

4 See Majluf and Myers [1984] and Greenwald. Stigliz and Weiss [1984]. Empirical suppon for these models is provided by Asquith and Mullins [1984] and in extensive related literature.
} 
to accelerator like behavior); and significant changes in the likely consequences of mactoeconomic policy.

However, financial markets are not the sole area of impact of imperfect information on macroeconomic behavior. Efficiency wage models of labor market ${ }^{5}$ behavior and comparable models of product markets ${ }^{6}$ have contributed imporandly both to understanding macroeconomic phenomena like unemployment ${ }^{7}$ and to investigating likely paths of adjustment berween macroeconomic equilibria. ${ }^{8}$ Thus the paper's basic model of financial market failures is extended to incorporate the impacts of these further informational imperfections in labor and product markets.

The paper consists, therefore, of five sections. The first two describe the impact of imperfect information in financial markets on investment and loan market behavior respectively. A third section incorporates these behaviors into a traditional IS-LM model of macroeconomic equilibria. The fourch section then briefly discusses an extension of the model to examine likely paths of adjustment between equilibria when labor and product markets also suffer from information imperfections. Finally, a fifth section investigates the long-run growth implications of the model.

I See Weiss [1980]. Shapiro and Stigliz [1984]. Stigliz [1974, 1976], Akeriof [1984], Bulow and Summers [1985] and Salop and Salop [1976] for examples.

6 See Stigliz [1987].

7 For surveys see Stigliz [1982, 1987] and Yellen [1984].

- See Greenwald and Stiglizz [1989]. 


\section{Section I. Firm Behavior and Investment}

The model of firm behavior which will be used is essentially that of Greenwald and Stiglitz [1987]. Firm decision makers maximize the expected end-of-period equity of the firm minus an expected cost of banksuptcy, which is simply the cost of bankruptcy times the probability of bankruptcy. ${ }^{9}$ We assume initially that firms use only circulating capital; inputs must be paid before outputs are available for sale and before output prices are known. ${ }^{10}$ Formally, therefore, firms

$$
\max \bar{a}\left(q_{1}\right)-c\left(q_{1}\right) P_{B}
$$

where $\bar{a}\left(q_{1}\right)$ is expected end-of-period equity, $c\left(q_{l}\right)$ is the cost of bankruptcy which we will assume is linear in $q_{1}$ (the size of the firm) so that $c\left(q_{1}\right)=c q_{b}, P_{B}$ is the probability of bankruptcy and $q_{t}$ is the firm's capital stock in period $t$ which is also, in this circulating capital world, the output that the firm has available for sale at the end of period $t$. Here end-of-period equity is

$$
\tilde{a}\left(q_{l}\right)=\overline{p_{l}} q_{i}-\left(1+\bar{r}_{l}\right) \bar{b}_{l} .
$$

where $\bar{p}_{1}$ is price of output at the end of period $t, \bar{b}_{1}$ is the firm's indebtedness at the beginning of period $t$ and $\vec{r}_{t}$ is the return to borrowers which is a random variable (as is $\dot{p}_{t}$ ) since the firm may go bankrupt and default on its loans. Then

$$
\bar{a}\left(q_{t}\right)=q_{t}-\left(1+\bar{r}_{t}\right) \bar{b}_{l}
$$

where $\bar{r}_{l}$ is the expected value of $\bar{r}_{l}$ and the expected price level is normalized at one.

Bankruptcy occurs if the end of period value of the firm, $a_{l}$, is less than zero; if

9 Similar results obcain if firms maximize an expocted utility (or valuation function) of end-of-period equity if the utility function is characterized by decreasing absolule risk aversion.

10 We assume that for a variety of informational reasons, fuaures markets are not a significant economic factor (see Greenwald and Stiglitz [1986]). 


$$
\bar{p}_{t} q_{t} \leq\left(1+r_{t}\right) \bar{b}_{t}
$$

where $r_{t}$ is the contractual level of interest that the firm promised to pay debtholders at the beginning of period $t$. The debt incurred by the firm at beginning of period $t$ is

$$
\bar{b}_{t}=w_{t} l_{t} q_{t}-a_{t-1}
$$

where we assume that output is produced with a constant-rerurns-to-scale technology using only labor as an input," $l_{t}$ is the amount of labor needed per unit of ourput, $a_{t-1}=p_{t-1} q_{t-1}-\left(1+r_{t-1}\right) \vec{b}_{t-1}$ is the equity level that the firm inherits from period $t-1$, and we assume for the moment that no dividends are paid out.

The cost of bankruptcy incurred here represents the cost to managers of the firm (i.e., those deciding on output levels). The justification for such bankruptcy costs is two-fold. First, in a world of imperfect information, outside observers cannot distinguish between failure due to incompetent management and failure due to bad luck (which is idiosyncratic to a firm in question). As a result failure will unavoidably stigmatize managers whether deservedly or not. The negative impact of this failure on their future earnings is, therefore, what is represented by the $\operatorname{cost} c\left(q_{t}\right) \cdot{ }^{12}$ Alternatively, the imposition of a punishment associated with failure may be one way to structure management incentive contracts which are characterized by sharing rules for positive profits but no means of credibly forcing managers to participate in losses. And, for these purposes, bankruptcy may be one natural point for assessing such penalties, since the ability of management to conceal losses is greatly reduced under such circumstances. Having bankruptcy costs increase with firm size then simply reflects the fact that a larger scale of operation

11 The restriction $w$ only labor inputs is made solely for expositional convenience. The effect of relaxing the constant-returns-to-scale assumption is examined in Greenwald and Stiglitz [1986].

12 The importance of bankruptcy iself in this regard is that it represents identifiable failure as opposed to other failures which may be at least parially obscured by accounting texibility. 
requires more managers. The advantages of this kind of interpretation of bankruptcy cost are, first, that it enables bankruptcy costs to play a larger role in firm decisions than estimates of actual reorganization cost, which are relatively small, would imply and, second, that relatively high bankruptcy costs of this kind account for the observed fact that bankruptcy is a rare event which managers appear to strive disproportionately actively to avoid. ${ }^{13}$ Finally, we will assume that reorganization costs to debtholders are zero.

We will assume that the contractual rate of interest paid by firms is set to yield an expected return to debt-holders which equals a required return, $\bar{r}_{t}$. For the moment we will assume that the equity constrained firms are not credit rationed.

Thus, each firm's decisionmakers maximize

$$
q_{t}-\left(1+\bar{r}_{t}\right)\left(w_{t} l_{t}\right) q_{t}+\left(1+\bar{r}_{t}\right) a_{t-1}-c q_{t} P_{B}
$$

where the probability of bankruptcy,

$$
\begin{aligned}
& P_{B}=F\left[\bar{u}_{t}\right], \\
& \bar{u}_{t} \equiv \text { price below which firms go bankupt }=\left(1+r_{t}\right) w_{t} l_{t}-\left(a_{t-1} / q_{t}\right),
\end{aligned}
$$

$F$ is the distribution function of $\vec{p}_{t}$ and the contractual rate of interest, $r_{t}$, is determined, simultaneously with $\bar{u}_{t}$, by the equation

$$
\left(1+\bar{r}_{t}\right)\left(w_{t} l_{t}-\left(a_{t-1} / q_{t}\right)\right)=\bar{u}_{t}\left(1-F\left(\bar{u}_{t}\right)\right)+\int_{0}^{\vec{u}_{1}} \bar{p}_{t} d F\left(\bar{p}_{t}\right) .
$$

In this last equation, the right-hand side represents the expected return required by borrowers per

\footnotetext{
13 In most models in which reorganization costs are small, kenders face imperfect information about the risks of investment projects and managers serve the interests of shareholders, managers should seek high risk projects which increase shareholder reums as the expense of lenders. Under these conditions one would expect bankruptcy to be a frequent occurrence.
} 
unit of output (i.e., the required return, $1+\bar{r}_{b}$, times the amount borrowed per unit of output). The left-hand side represents the actual expected return to borrowers per unit of output as a function of $\bar{u}_{t}$. The definition of $\bar{u}_{t}$ implies that the return from selling the output $q_{t}$ at $\bar{u}_{t}$ just covers the contractual return to debtholders (i.e., $1+r_{1}$ ). At prices below $\bar{u}_{1}$, the returns to debtholders are just $\dot{p}_{t} q_{t}$ (since they receive the entire proceeds from sales of output) or $\dot{p}_{t}$ per unit of ourput.

The optimal level of output (and hence investment), $q_{1}$, which solves this maximization problem depends positively and linearly on $a_{t-1}$, since the maximand, on being divided by $a_{t-1}$, is a function of $\left(q_{t} / a_{1-1}\right)$ and $\bar{u}_{t}$ depends on $q_{t}$ only through $\left(q_{t} / a_{t-1}\right){ }^{14}$ The first order condition determining the optimal level of $\left(a_{t} / a_{t-1}\right)$ takes the form

$$
1=\left(1+\bar{r}_{t}\right) w_{t} C_{t}+c P_{B}+c \frac{d \bar{u}}{d\left(q_{t} / a_{t-1}\right)}\left[\frac{q_{1}}{a_{t-1}}\right] \frac{d P_{B}}{d \bar{u}} .
$$

The left-hand side of this equation is the expected end-of-period return to output (investment) and the right-hand side is the expected marginal cost of output including the marginal increase in bankruptcy costs associated with higher levels of output (the second and third right-hand side terms). The output (investment) function of a typical firm can, therefore, be written as

$$
q_{t}=h\left(w_{1}, r_{t}, \sigma_{t}\right) a_{t-1}
$$

where $\sigma$, represents the spread of the price distribution, $F$, and

$$
h_{w}<0, h_{r}<0 \text { and } h_{\sigma}<0 .
$$

The levels of firm output and investment depend not just on the expected return to investment, which depends in turn on wages and interest rates as it does in the traditional case, but also

14 This result depends on the constant-returns-to-scale production assumption and assumptions on the distribution $F$ necessary to ensure that the second order condition is satisfied (see Greenwald and Stiglitz [1986] for details) which are quile general. 
on the firm's equity level and the level of uncerainty conceming future prices. Higher equit. levels mean that the same level of output (and hence investment) can be attained with a lower level of borrowing and thus with a lower risk of bankruptcy. Moreover, under quite general circumstances (e.g., if bankouptcy is an event which occurs in the lower tail of a single-peaked distribution of prices), then higher equity levels also lower the incremental risk of bankruptcy associated with any given level of output (investment). This means that higher equity levels reduce the incremental cost of higher output and, thus, lead to increased output and investment.

Increased uncerainty about future profitability has an opposite effect. Greater uncerainty increases both the absolute and incremental risk of bankruptcy under quite general conditions at any level of investment (output) and firm equity. Thus, firms respond by lowering investment (and output), since they cannot absorb the increased risks by issuing more equity.

Complete specification of the output and investment model then requires an equation describing the evolution of equity levels. Substitution from the definitions of $\bar{b}_{1}$ into the definition of $a_{t}$ yields

$$
\bar{a}_{t}=\bar{p}_{t} q_{t}-\left(1+\bar{r}_{l}\right)\left(w_{t} f_{l}-a_{t-1}\right) .
$$

Thus, firm equity levels in period $t$ are firm equity levels in period $t-1$ plus profits (including a shadow return on $\left.a_{t-1}\right)$. The critical assumption here is that a firm does not have recourse to external equity markets.

The formal rationale for such an assumption is developed in the Appendix to this paper. However, it is straightforward to describe the arguments involved. Suppose that in addition to the level of output, $q_{l}$, prices, wages and interest rates, the profitability of each firm depends on an unobservable productivity variable. If all firms look identical to potential investors, then firms with high levels of unobserved productivity (and hence future profits) will sell stock on the 
same terms as those with low levels of unobserved productivity. However, the cost of selling any given amount of stock is higher for the high productivity firm since the shares that it sells represents a portion of a higher level of profits. Thus, only low productivity firms would sell stock on these terms. ${ }^{15}$ However, in doing so, they would identify themselves as low productivity firms with a resulting negative impact on their current market values. If, therefore, firms (or their managers) are concerned with the current as well as the future market values of their equity, this second effect may deter even low productivity firms from issuing equity.

Allowing for dividends leads to only a slight modification of the equity equation as long as dividend levels are fixed. Then, the end of period equity of the firm becomes

$$
\dot{a}_{1}=\dot{p}_{1} q_{t}-\left(1+\dot{r}_{1}\right)\left(w_{t} l_{t}-a_{t-1}\right)-d_{l}
$$

where $d_{t}$ is the level of dividends. The rationale for such an assumption is similar to that for restricting equity issues. Dividends are negative equity issues to which a firm has made a prior commitment. Only low productivity firms with a high incremental value for such funds as protection against bankruptcy would seek to abandon this commitment and the consequent negative signal involved should discourage such changes. ${ }^{16}$

If a firm is, in addition, constrained in the amount of debt that it can issue and that constraint is binding, then the output function is even simpler. Let $b_{t}$ denote the maximum level of allowed borrowing, then

$$
w_{t} l_{t} q_{t}=\text { dollar amount of investment }=\left(a_{t-1}+b_{t}\right)
$$

\footnotetext{
is The value of equity in providing protection against bankerpecy is also greater for low than high productivity firms, since low productivity firms are in greater danger of bankruptey.

16 In practice. since dividend levels typically involve an implied promise of continuity, reducing dividends to obrain equity funds is likely to be less appealing than issuing equity since the curren equity yield is likely to be smaller.
} 
which is inherited equity plus the level of borrowing allowed under the credit constraint. If the output (investment) of these firms is added to that of firms which are merely equity constrained, then the aggregate investment function will now include the allowed borrowing level, $b_{1}$, as an explanatory variable. The investment function of equation (3) can thus be rewritten as

$$
q_{t}=h\left(w_{t}, \bar{r}_{t}, \sigma_{t}, a_{1-1}, b_{t}\right)
$$

where $b_{1}$ represents the level of rationed credit and $h_{b}>0$.

Extending the circulating capital model to incorporate investment in long-lived physical capital is principally a matter of redefining the production period. Consider a firm whose sole investment project consists of a plant with a fixed life of $T$ periods. Assume for simplicity that funds borrowed to support the plant are due to be repaid (including accrued interest) at the end of period $T$, that input costs and output revenues are contemporaneous in each subperiod $t=1, \ldots T$ (or at least are subject to minimal uncertainty looking forward from the beginning of each sub-period) and that intervening subperiod profits are reinvested at a safe rate of retum $r_{t}$, the end-of-period $T$ retum to the plant investment is

$$
\bar{\pi}_{T} \equiv \sum_{t=1}^{T} \bar{\pi}_{t}(k)\left(1+r_{t}^{*}\right)^{T-t}
$$

where $\bar{\pi}_{t}(k)$ is the profit in subperiod $t$ looking forward from the time of the initial investment which is a random variable and a function of that initial investment, $k$. The end-of-period $-T$ equity of the firm is then

$$
\bar{a}_{T}=\bar{\pi}_{T}(k)-\left(1+r_{0}\right)^{T} b_{0}
$$

where $b_{0}$ is the level of initial borrowing and $r_{0}$ is the contractual rate of return on that borrowing. If $\bar{a}_{T}$ is less than zero, the firm goes bankrupt and incurs a bankruptcy cost proporional to its scale of operation, $k$. Finally, initial borrowing by the firm is simply 


$$
b_{0}=p_{k} k-a_{0}
$$

where $p_{k}$ is the price of capital goods and $a_{0}$ is the initial equity of the firm.

If $\bar{\pi}(k)$ is linear in $k$ (i.e. constant-retums-to-scale), this long-run investment problem is identical in structure to the circulating capital formulation described above. Thus, nothing in the model restricts the definition of investment to circulating capital and the basic implications of financial market imperfections in the circulating capital model, (e.g. the dependence of investment on both inherited equity and the unsertainty of the economic environment) ${ }^{17}$ can apply equally well with fixed capital investment.

Several points should be made about the nature of aggregate (and individual firm) investment behavior implicit in equations (4) and (5). First high profitability in any given period by generating increases in firm equity levels (for non-credit constrained firms) and increased cash flow (for credit constrained firms) will lead to increased future investment. Thus, the model suggests the kind of significant relationship between current operating cash flow and investment found by Hubbard, Fazzari and Petersen [1988], among others. Also, if high profitability in any period is related to increases in demand in that period, the model will exhibit the kind of accelerator behavior that has been so successful in explaining actual investment behavior. ${ }^{18}$ The model can be usefully thought of, therefore, as providing a microeconomic rationale for both the cash flow and accelerator aspects of inveswent behavior that appear to play such a significant role in practice. 19

\footnotetext{
17 However, in practice, there are complications incroduced by the existence of tong-lived capilal. If loans are made on a shor lem basis, then a bankouptcy constraint musa be defined for each sub-period, $t$, which, in um, requires that there be some means of valuing fxed capival at these intervening times. Doing this is nol straightforward. Also, firms typically invest in both fixed and working capital. Thes, each individual decision period entails choices of both long-lived invesument and current output the interaction of these two kinds of decisions aiso significantly complicates the andysis, although it does not change its fundamental implications.

18 See Eirner [1967]. Jorgensen [1963] and Lintner [1971] for examples of a large literature.

19 A second accelerator like effect also arises if there is fixed capital and increases in demand for a firm's output is persistent. Then past increases in oupue and profitability are likely to be indicalors of fuure profitability which
} 
The role of interest rates in determining investment may be circumscribed in two imporant ways. First, the critical rate in the model is that facing firms not some average rate on all assets. With imperfectly informed lenders, changes in general market rates do not necessarily lead to changes in the rates charged to borrowing firms. ${ }^{20}$ Some part of the shift in loan supply is absorbed by increased credit rationing since charging higher interest rates has an adverse effect on the quality and riskiness of the borrower pool (see below). Thus, the rate, $r_{1}$, (and the associated expected return to lenders $\bar{r}_{t}$ ) which enters the investment model above may vary significantly less than widely observed market rates which would be available for use in any empirically estimated investment equation. Second, the impact of interest rates tends to be small relative to the impact of changes in a firm is financial position, ${ }^{21}$ and real interest rate series have until the quite recent past been observably quite stable. Thus, the variability in the financial positions of firms and the perceived riskiness of the environment they face over the business cycle can be responsible for a far greater share of the variation in investment over time than market interest rates. For both reasons, the model provides an explanation for the relatively small and elusive role that interest rates play in empirical investment equations and suggests that interest rates themselves do not play a primary role in macroeconomic stabilization. ${ }^{22}$

would raise the value of a firm's fixed capital slock. In a world without informational imperfections, any such increases in future proficability would be reflected in the market values of firms and would enter a classical investment equation through Tobin's $q$. In a model with imperfect information, it is the perception of the manager's of a firm, based on their private information, which matter and these penceptions mauer in two distinct ways. First, parallel to the classical effect, a rise in future expected retum (i.e. an increase in expected prices relative to $w_{l}$ ) will directly elicit higher levels of oupul. But, in addition, higher future profitability increases the flow of future equity funds and affects output (investment) through that channel as well. In practice, of course. stock market valuations and internal firm assessments may be highly correlated, especially in cross-soctional data, so that the two models will be hard to distinguish. Nevertheless there are important differences berween the two. For example, in the past, stock market values have appeared to fluctuate with any clear relacionship to future firm profilability and cash flow. Such fluctuations would affect Tobin's $q$ and invesument in the classical, but would not affect investment in the model presented here.

20 See Stigliz and Weiss [1981] and the discussion below in Section II.

21 See Groenwald and Suiglizz [1986].

2 These same factors also explain why properly specified nea-classical investment models like those of Abel [1980] and Abel and Blanchard [1986] perform relatively less well empirically than simple accelerator models. 
Finally, as will be noted extensively in later sections of this paper, investment, although defined for explanatory purposes as investment in physical capital of the usual sort, need not and should not be interpreted so narrowly. Part of investment takes the form of working capital and the hiring and training of workers and a rise in the cost of investment (because, for example, of a deterioration in a firm's equity position) will be reflected as a reduction in working capital, in employment, and, since the costs of working capital and hiring are part of the costs which determines aggregate supply, in aggregate supply and labor demand. Pricing, too, may have an imporant investment component. If future demand depends on current sales, then firms will invest in furure demand by lowering current prices and expanding current sales. ${ }^{23}$ An increase in the cost of investment will consequently appear as an increase in curtent prices and a reduction in current output as firms respond by reducing investment in future demand. Again, therefore, a reduction in investment will appears as a reduction in current supply. Productivity growth may also have an important investment component both through research and development spending, the learning associated with implementation of new technologies embodied in fixed capital invesument and learning-by-doing related to higher current ourput. Thus, the idea of investment should not be narrowly construed as relating solely to fixed investment and in what follows we will take such a broad view.

\section{Section II: Credit Rationing and Loan Markets}

In describing loan markets, this section will focus on the role of bank lending. The justification for doing this is threefold. First, cyclical changes in firm financing are dominated by changes in shor term bank financing. This is especially true at the peak and during the

2 See Phelps and Wincer [1971] for a model of this kind. 
downward phase of the cycle. ${ }^{24}$ Second, the role (or lack of role) of monetary policy is central to mactoeconomic theory and, in most modern industrial societies, the proximate impact of monetary policy is on the banking system. Therefore, in examining the role of monetary policy, the banking system is a logical point of departure. Finally, a model of loan markets based on bank lending appears relatively easy to extend to incorporate direct lending to firms, whereas the opposite - extending a direct loan model to incorporate a banking system - seems to be less straightforward.

We will assume, following Stiglitz and Weiss [1981], that lenders are unable to distinguish among borrowers, that borrowers accept a common fixed loan size and that as the contractual rate of interest charged borrowers rises the quality of the borrower pool falls. ${ }^{25}$ This occurs because the pool of borrowers at high contractual interest rates consists to a disproportionate degree of those who, because they have high expected default rates, do not face comparably high expected interest rates. This means that as contractual interest rates rise, the expected returns on loans may first rise, but ultimately fall as the cost of deterioration in the borrower pool outweighs the direct gains from higher contractual rates. At the same time, the variance of loan retums should rise steadily with rising contractual rates of interest as default rates arise. Changes in contractual rates of interest will, therefore, trace out a mean-variance frontier of loan returns as illustrated in figure 1 . We will assume that the expected return on this frontier peaks at a contractual interest rate $r_{m}$ corresponding to an expected lender return $\bar{r}_{m}$ and a return standard deviation, $\sigma_{m}$.

Next we assume that lenders (banks) have a choice of investing in risky loans along this

\footnotetext{
24 See Zamowitz [1986].

25 See discussion in Appendix concerning loan sizes and the information to be derived from observing loan sizes.
} 
frontiet or in safe govermment bonds which pay a retum, $r_{l}^{8}$, in period $t$. In making this choice we assume that banks are risk averse and characterized by declining absolute risk aversion as their financial positions improve. ${ }^{26}$ Like some of the firms to which they lend, banks are assumed to be run by manager/decision-makers who are not fully diversified (i.e. they are disproportionately invested in the banks that they manage).

A useful starting point is to consider a case in which loan demand at any interest rate below $r_{m}$ exceeds the total lending capacity of banks. Then banks will always ration credit and the efficient investment frontier for a bank runs along a line from the point $r_{l}^{8}$ on the vertical axis to a tangency with the mean-variance loan retum frontier traced out by varying contractual rates of interest (see figure 1 ) as long as $r_{l}^{8}$ is below $\bar{r}_{m}$. At interest rates on govermment bonds above $r_{m}$. banks invest entirely in government bonds. The tangency point on the loan return frontier determines the terms on which bank loans are made. It necessarily occurs at an expected retum at or below $\bar{r}_{m}$ and, thus, entails a contractual loan rate at or below $r_{m}$. The fraction of the bank's assets devoted to commercial loans (on the terms determined by the tangency of the efficient frontier and the loan return frontier) is then determined by the tangency of the bank decision maker's mean-variance indifference curve with the efficient frontier. This too is shown in figure 1. The position of this tangency point depends on several factors.

As $r_{i}^{\beta}$ falls toward zero, the point of tangency on the loan frontier may move only very slightly, especially if the frontier has a shape like that shown in figure 1. As a result, the contractual rate of interest charged borrowers may be highly insensitive to changes in the rate of interest in public securities markets. Nevertheless, as $r_{1}$ falls the tangency of the efficient frontier with

\footnotetext{
26 Note that this represents a departure from the perfectly informed, risk neutral lenders of Section I. However. accommodating such behavior does not fundamentally alter the characteristics of the firm level model.
} 
the bank indifference curves may change substantially leading to a significant change in bank lending.

As the financial positions of firms improve, the quality of the overall borrowing pool improves, since firms are less likely to default. This appears as a shift upward in the loan retum frontier, since at each contractual rate of interest the expected return on loans rises and the variance of returns falls as default rates decline. The slope of the efficient frontier will then become steeper and the tangency of the frontier with the decision makers indifference curve will move to the right (i.e. to a steeper point on the indifference curve) ${ }^{27}$ Thus, the optimal bank portfolio will consist of a greater fraction of loans and a smaller fraction of govermment bonds. A reduction in the interest rate on the government bonds will have a similar effect. An improvement in the financial position of a bank can be interpreted as a flattening of the risk-return indifference curves (because of declining absolute risk aversion) and hence a shift to the right in their tangency with the efficient frontier. This implies a greater fraction of commercial lending and less investment in the safe government asset. ${ }^{28}$

The actual level of bank commercial lending is the product of the share of loans in the bank portfolio and the level of bank assets. The latter is, in turn, just the sum of bank capital and deposits. Since we will assume that the money supply consists only of deposits and that reserve requirements are negligible, deposits will be equal to the money supply. Thus total loans are

\footnotetext{
27 This is not quite the whole story. The point of tangency with the loan return frontier will also stift - under most circumstances - w the left. Thus the share of loans represented by any point along the horizontal axis will increase and the wotal increase in the loan share in the bank's portfolio will consist of the combined effects of the shif in the tangency with the indifference curve and the shift in tangency with the loan retum frontier. Also, as the tangency with the loan return fronties changes the contractual rale of interest charged 10 firms changes.

20 Altematively, the increase in the bank's financial position could be interpreted as a shift upward in all expected returns (as net bank profits increase), if these are reinterpreted to reflect net bank profits after paying interest on bank liabilities. This would move the whole picture to a region of the indifference map with flatuer indifference curves (since absolute risk aversion has declined).
} 


$$
b_{t}=\left(\frac{M_{t}}{P_{t}}+\gamma_{t-1}^{b}\right) \beta\left[r_{t}^{g}, a_{t-1}, a_{t-1}^{b}\right]
$$

where $1 \geq \beta \geq 0$ is the fraction of bank assets loaned which depends on $r_{l}^{g}$, the rate of return on government bonds, $a_{t-1}$, borrowing firm equity positions and $a_{t-1}^{b}$, the equity position of banks as they enter period $t$ with $\beta_{1}<0, \beta_{2}>0$ and $\beta_{3}>0$. The variable $\gamma_{t}^{b}$ is bank capital in period $t, M_{t}$ is the nominal money supply and $P_{t}$ is the price level, all magnitudes except those last two being real variables.

The contractual rate of interest on loans in the rationing equilibrium is

$$
r_{t}=\alpha\left(r_{t}^{8}, a_{t-1}\right) \alpha_{1} \geq 0,
$$

and $\alpha_{2}$ may be either positive or negative. The level of bank equity does not affect $r_{t}$ in the rationing equilibrium because $r_{t}$ depends only on the tangency of the efficient frontier with the loan return frontier. If at this contractual interest rate the demand for loans is less than the amount that bank porfolio decisions make available (i.e. there is no credit rationing), then competition among banks will drive down the contractual rate of interest (given that loan size remains fixed as in Stiglitz-Weiss [1981]). As this occurs bank loan returns move down along the loan return frontier. The available efficient porfolio frontier under these circumstances runs from the point $r_{t}^{8}$ on the vertical axis (see figure 1a) to the point of the loan retum frontier corresponding to a particular contractual interest rate. Along this new frontier banks select a portfolio mix at which it is tangent to their risk-retum indifference curves. At this tangency lower contractual retums will lead to less loan investment by banks and hence lower loan supply. At the same time lower contractual rates of interest increase loan demand. At some point the two just balance and an equilibrium without credit rationing occurs. However, under these conditions, $r_{t}$ still depends on $r_{t}^{8}$ and $a_{t-1}$ which affects both loan demand and the position of the 
loan return frontier. ${ }^{29}$

In order to complete the loan sector of the model, we must specify how bank equity and bank capital evolve over time. For simplicity we assume that bank capital may come only from reinvested earning. Bank capital borrowing and new equity, like those of other firms, will be assumed to be impossible. ${ }^{30}$ Formally, therefore,

$$
\gamma_{t-1}^{b}=\pi_{l-1}^{b}+\gamma_{t-2}^{b}-d_{l-1}^{b}
$$

where $\pi_{t-1}^{b}$ is bank profitability and $d_{-1}^{b}$ is bank dividends in period $t-1$.

The restrictions on capital borrowing and new equity issues might suggest that bank capital is also bank equity. However, that is not the case. The equity of the bank looking forward from the beginning of period t includes the value of the bank's franchise as perceived by its managers. This will depend, if there are restrictions on entry and deposit interest, on level of the expected future money supply and thus, in tum, on current monetary policy. To keep things as simple as possible we will assume formally that

$$
a_{t-1}^{b}=\gamma_{t-1}^{b}+\mu_{t-1}
$$

where $\mu_{t-1}$, the value of the bank's franchise depends upon current and expected furure monetary policy.

The availability of credit to firms and the terms on which credit is made available, therefore, depends on the financial condition of the firms themselves and that of the banking sector, which reinforces the cash flow and accelerator-like investment behavior noted in Section I. Monetary policy affects loan conditions through a number of channels. First, and perhaps least

29 If banks can distinguish among calegories of potential borrowers this process of increasing laan demand will entail the making of the loans to successively less auractive groups and rationing the marginal group in equilibrium.

30 The borrowing restriction here has no significant impact on the implications of the model. 
importandy, money policy will affect the interest rate on government bonds. Second, changes in monetary policy will lead to changes in the equity of banks due to changes in the perceived value of their franchises. ${ }^{31}$ Third, monetary policy increases the assets in the hands of banks that are available for loans to firms. This last effect is an artifact of the assumed restriction of lending in the model to banks. Monetary policy which shifts control over financial investment funds from households to banks naturally increases lending to firms if only banks are able to do this. However, to the extent that banks enjoy special advantages in making loans to furms a similar impact, but one of lesser magnitude, would occur even if direct lending to firms were allowed. Allowing banks to borrow for capital purposes would also offset this third effect, but again (in the absence of perfect capital markets and perfect deposit competition) only partially.

\section{Section III. The Macroeconomic Model}

The changes introduced into a standard macroeconomic framework by incorporating the effects of financial market imperfections are extensive. However, much of the familiar structure of the traditional model can be preserved. If the inherited equity levels of firms $\left(a_{t-l}\right)$, and the level of environmental uncerainty $\left(\sigma_{t}\right)$ are treated for the moment as exogenous parameters, then a goods market equilibrium (suppressing these parameters for notational convenience) can be written

$$
y_{t}=i_{t}\left(r_{t}, b_{t}, w_{t}\right)+g_{t}+c_{t}\left(r_{t}^{g}, y_{t}\right)
$$

where $y_{t}$ is real output, $g_{t}$ is real government spending and $c_{t}$ is real consumption which is assumed to depend on the level of output and the interest rate on government bonds, $r_{t}^{8}$, which is

\footnotetext{
31 This is similar in spirit, but likely to be more significant in magnitude than the wealth effect of monetary
policy.
} 
assumed to be the interest rate available to consumers. ${ }^{32}$ The principle difference from the traditional IS curve is that financial market conditions are no longer embodied in a single interest rate variable, but rather in one interest rate facing consumers $\left(r_{t}^{8}\right)$ and two variables $\left(r_{t}, b_{l}\right)$ which capture the loan market conditions, involving both price and quantity rationing, facing firms.

The financial market equilibrium (LM-curve) interacting with the goods market described above implicitly consist of four financial markets: (1) a money market equating the supply and demand for demand deposits, (2) a govemment bond market equating the demand for government bonds to the existing supply. (3) the market for loans described in the previous section and (4) a market for the fixed amount of outstanding common stock of firms.

The last of these markets can be ignored in the analysis which follows. This stock market can be thought of as equilibrating the supply and demand for shares through the determination of a stock price per share. Since equity sales are excluded in the model, this stock price does not influence investment and, since consumption does not depend on perceived wealth, it does not affect consumption demand. ${ }^{33}$ Nor need its interaction with other asset markets be considered. Strictly speaking stock price should enter the demand curves for both money and government bonds (and loans if banks were allowed to own common stocks), but in this case the stock price could be eliminated by solving for stock prices from the stock supply and demand equation and substituting into the money and government bond market equations.

Similarly, the money and government bond demand equations can be solved to yield a reduced form equation for the govemment bond interest rate in terms of the real supplies of

32 This consumption function which is common to traditional macrocconomic models is used for the sake of simplicity. A full general equilibrium model with intertemporal consumer utility maximization is developed in Greenwald and Sugliz [1986]. A model with a consumption function modified to take account of permanent income in a rational expectations context is developed in Greenwald and Stiglitz [1988]. Another general equilibrium altemative is developed by Woodford [1988].

33 Relaxing this condition would complicate the analysis without altering its fundamental conclusions. 
government bonds and money and the level of output, $y_{t}$, which presumably affects money demand. This is roughly equivalent to a traditional LM curve and will be written formally as

$$
r_{t}^{8}=l\left(y_{t}, \frac{G_{t}}{P_{t}}, \frac{M_{t}}{P_{t}}\right], l_{1}>0, C_{2}>0, C_{3}<0
$$

where $G_{\text {, }}$ is the outstanding nominal amount of government debt.

The principal innovation that arises from credit rationing is the introduction of equations (4) and (5) describing the loan behavior of banks. These determine $r_{t}$ and $b_{t}$ as functions of $r_{l}^{8}$ given the equity positions of banks, $a_{i-1}^{b}$; the equity positions of borrowing firms, $a_{1-1}$; the levels of environmental uncertainty $\left(\sigma_{t}\right)$ and wages $\left(w_{t}\right)$ which affect the demand for bank loans; and the levels of bank capital $\left(\gamma_{1-1}^{b}\right)$ and the money supply $\left(M_{t} / P_{t}\right)$ which determine bank resources. For analytical purposes, because two loan market variables are involved, the simplest approach is to incorporate the loan market equilibrium into the IS curve by substituting from equations (4) and (5) into the investment function of equation (6). This yields a goods market equilibrium of the form

$$
y_{t}=i_{t}\left[r_{t}\left(r_{t}^{8}, \frac{M_{t}}{P_{t}}, w_{t}\right], b_{t}\left[r_{t}^{8}, \frac{M_{t}}{P_{t}}, w_{t}\right]\right)+g_{t}+c_{t}\left(r_{t}^{8}, y_{t}\right)
$$

where the variables $a_{t-1}, a_{t-1}^{b}, \gamma_{t-1}^{b}, \sigma_{t}$ and $q_{t-1}$ have been suppressed as parameters. Since $r_{t}$ is increasing and $b_{t}$ is decreasing in $r_{l}^{\&}$, an increase in $r_{l}^{8}$ reduces investment demand and hence aggregate demand. This credit-rationing-modified IS curve is, therefore, downward sloping in the usual way.

The traditional macroeconomic equilibrium is then depicted in figure 2 with the intersection of the IS and LM curves determining an equilibrium level of output and the government bond interest rate for any given tevel of real wages. It also has several familiar properties. An 
increase in govemment debt shifts the LM curve upward leading to an increase in interest rates and a reduction in output. ${ }^{34}$ Also the model is characterized by the standard neutrality result. If the government debt and money supply are increased proportionately, then prices increase in the same proportion and real magnitudes are unchanged. The same result arises, if the taxes required for debt service are fully discounted by taxpayers and the money supply increases.

However, there are significant differences from a traditional macromodel. In particular an increase in the (real) money supply shifts both the LM curve downward and the modified IS curve to the right, since such a shift directly increases bank lending. As a result it is conceivable given the relative magnitudes of these shifts that an increase in the money supply could lead to higher equilibrium output and higher interest rates on government bonds. And, since monetary policy affects the IS curve directly, its effect on total output is likely to be far more significant than that of government debt operations alone which affect only the LM curve. This seems to be borne out by empirical observations. The added potency of money supply changes arises because it shifts resources into and out of the hands of financial institutions with particular access to borrower information.

Furthermore unanticipated monetary policy may have stronger impacts still. Assuming that most firms have nominal liabilities (bonds, bank debt, taxes payable, etc.) and real assets, an unexpected monetary expansion may lead to a transfer from lenders (ultimately households) to firms, enhancing the equity positions of firms. This would lead to a further rightward shift in the IS curve, a further increase in output and more upward pressure on interest rates.

\footnotetext{
34. This assumes that the increase in the supply of government debt is not completely offset by an increase in demand for government debt in anticipalion of higher future taxes. Moreover. since the consequences of the source of the increase in debt (i.e. higher government spending or lower taxes) are not considered the change should be interpreted in terms of a comparison of a high debi economy (for historical reasons) to a low debt economy.
} 
Another exogenous factor which exerss a particular influence in this credit and equity rationing model is an increase in the incertainties faced by individual firms. In practice, this could comespond either to an increase in the overall rate of inflation (which has empirically been related to increased relative price fluctuations and to increased variability in rate of inflation) or to an increase in the unpredictability of monetary policy (as in 1979-82). Such an increase in uncerainty would reduce investment demand both directly and indirectly through its effect on bank lending terms. The IS curve of equation (8) would shift to the left and equilibrium output and real interest rates would fall (although the change in actual loan rates might be small).

The model is completed by an equilibrium in the labor market which determines the real wage, $w_{t}$, as a function of the IS-LM equilibrium. The labor demand curve in this market is just the marginal product of labor at a given level of output net of the incremental risk of bankruptcy borne by managers as output (and employment) increases. This is a downward sloping marginal product curve of the usual sor as shown in figure 3. However, this labor demand curve shifts with the financial position of firms. An improvement in a firm's equity position reduces the incremental risk associated with increased output (and employment) at any given output level. Thus, unanticipated shifts in monetary policy which lead to changes in firm equity positions will shift the labor demand curve. Similarly, credit rationing restrictions and the cost of paying workers in advance of production may change the marginal product of labor (net of associated material and interest costs) in response to changes in loan market conditions.

The labor supply relationship may be embodied in either an upward sloping supply curve of the usual sor or a no-shirking constraint of the kind developed in Shapiro and Stiglitz [1984]. In both cases, shifts in policy which change the labor demand curve (by inducing shifts in either firm equity positions, loan market conditions or the uncerainty of the economic environment) 
will lead to changes in equilibrium employment, wages and output (see figure 3). In the case of a labor supply function there will be no associated unemployment. In the case of a no-shirking constraint (efficiency wage) model the shift in the labor market equilibrium will be associated with a change in unemployment. In both cases the change in wages will tend to offset, but only partially, the contemporary change in output at constant wages predicted by the IS-LM interaction along. Finally, it should be noted that these changes in output may be relatively short-lived (in contrast to the supply effects of capital accumulation in overlapping generations models), since firm financial conditions may change relatively quickly (along with loan market conditions), and they do not depend on any arbitrary nominal price rigidities (in contrasts to traditional Keynesian models).

\section{Section IV. Short Term Adjustment}

The equilibrium shift in output and wages implied by a particular movement in the labor demand curve (see figure 3 ) should, given the likely slopes of either the labor supply or the nonshirk constraint curve, involve significant changes in both wages and output (employment). However, with imperfect information the adjustment path to the new equilibrium is likely tc involve large initial changes in output (employment) and only small changes in wages. This possibility is based on three simple assumptions in addition to the assumption that firm decision makers are risk averse; namely, that firms are uncerain of the impact of their actions, that this uncertainty increases with the size of movements from the status quo and that uncertainties associated with price and wage changes are greater than those associated with quantity changes (e.g. in output or unemployment). The first two of these assumptions should be uncontroversial, but the last is central and requires some explanation which will be provided below. 
The reason that rates of adjustment concerning the impacts of different decision variables are related to their relative uncertainties can be seen intuitively as follows. If firms are risk averse, then they will consider both the mean and the variance of the returns yielded by different combinations of changes in decision variables. As firms make adjustments, the expected value and the variance of profits change together. However, if uncerainty concerning the impact of one decision variable $A$ (a price) is greater than uncerainty concerning the impact of another decision variable $B$ (a quantity), then, other things being equal, the optimal portfolio of adjustments will contain less movement in $A$ than $B .{ }^{35}$ Following such initial changes which are greater in $B$ than $A$, the expected returns to further changes in $A$ are likely to rise relative to the expected returns to changes in $B$ (since $B$ will now be closer to its new optimal value). Thus, ultimately $A$ may adjust as extensively as $B$, but in the shor run $A$ will exhibit ineria relative to B.

One important qualification must, however, be made to this simple description. When the consequences of actions are particularly uncertain, and firms are particularly risk averse, it is sometimes suggested that firms will simply maintain the status quo. But what does it mean to continue doing what you were doing before? Does it mean keeping absolute prices fixed or reladive prices? Absolute wages, or relative wages? We provide here an answer: very risk averse firms will take those actions which minimize the variability of their profits. Thus, in speaking in the previous paragraph of the magnitude of changes in $A$ relative to $B$, these must be interpreted as changes from the minimum variance point not as changes from pre-existing levels. If the economic environment is one in which the variance of profit is related to relative wages or prices, firms will minimize variance by keeping relative wages or prices fixed. Thus, in the

35 Where uncerainty here is appropriately defined in lerms of the covariance matrix of uncerainues concerning the impacts of the several decision variables. 
present model, the minimum variance response is one of no change in real magnitudes. ${ }^{36}$

The arguments just given imply that immediate term movement in real wages from the no change point will be relatively small compared to those of output and employment, if firm decision makers face relatively large uncertainties about the effects of wage changes. In efficiency wage models this is likely to be the case. The usual efficiency wage assumption is that average productivities can be observed accurately. Thus, if a large group of workers is laid-off or not replaced (where there is substantial normal numover), the lost labor supply is just the number of workers involved times average productivity. There is little or no uncertainty about this. However, firms are likely to be much less certain of the impact of a wage change on labor supply since this involves estimating the impact of wage changes on turnover (both in quality and quantity) and worker performance. Neither is likely to be known very accurately nor can these effects be ascertained immediately following any initial wage change (they take time to become manifest). The result will then be a pattem of adjustment characterized by rapid output and employment changes and small wages and price changes that is very similar to what is observed in practice.

\section{Section V. Long Term Dynamics}

The long run dynamics of the model are driven by rates of accumulation in capital and equity. For simplicity, we will assume that bank and firm capital grow in proportion (because of structures of relative profitability in banking and production activities) and that $\sigma_{t}$, the environmental uncerainty, is fixed. The IS-LM-labor demand-labor supply equilibrium for given real money and real government debt levels can be solved to yield a level of equity accumulation as a

\footnotetext{
36 These arguments are developed in Greenwald and Stiglitz [1989].
} 
function of $a_{t-1}$ and presumably $k_{t}$. In this reduced form function

$$
i_{t}=g\left(k_{1}, a_{8-1}\right), g_{1}>0, g_{2}>0 \text {. }
$$

Higher levels of firm equity (and higher levels of physical capital) tend to lead to higher levels of output and investment. In steady-state, investment must replace depreciation and equip new workers entering the labor force (if the labor force is growing). Thus, in steady-state

$$
i=(\delta+n) k=g(k, a)
$$

where $n$ is the rate of growth of the labor force, $k$ and $a$ must now be interpreted as per capita magnitudes and we assume constant retums to scale (including in the bankruptcy cost function). In a general equilibrium context, $g_{1}$ should be less than $\delta+n$ (because increased capital which increases wages and interest rates has a relatively small general equilibrium effect on new investment demand). Under such a condition, the steady-state levels of $a$ and $k$ in equation (9) are related by an upward sloping curve (see figure 4). This is essentially an equity demand curve. It describes the level of equity per capita in steady-state which is required to generate sufficient investment to sustain a particular level of the per capita capital stock. For levels of $a$ below this curve, the per capita capital stock will be declining. For the levels of $a$ above the curve, $k$ will be increasing.

A second steady-state relationship exists between $k$ and $a$ which can be described as an equity supply curve. Higher levels of both the capital stock and equity tend to increase output, drive up wages and ultimately reduce profits and retained earnings. Since retained earning are the source of equity growth and equity per capita must grow in steady-state at a proportional rate $n$, the steady-state equity demand relationship is

$$
n a=h(k, a), h_{1}<0, h_{2}<0
$$


which is a downward sloping curve (see figure 4). Where this second curve intersects the equity: demand curve is the long-run steady-state of the equity and credit rationing model. A simple phase plane analysis indicates that the equilibrium is stable with dynamic paths which may either return monotonically (most likely) or cyclically to equilibrium. Thus, temporary deviations in firm equity levels, due for example to unexpected money supply changes, are ultimately eliminated as the model retums over time to the long run steady-state. Cycles in these models appear, therefore, like most observed business cycles to be self-limiting.

This long-run steady-state can also be used to study long-run comparative statics. For example a sudden increase in uncerainty $\left(\sigma_{l}\right)$ shifts the equity demand curve upward and yields a new steady-state with lower capital and higher equity levels. ${ }^{37}$

\section{Section VI. Conclusion}

The important point to note about the macroeconomic implications of even the relatively simple model of credit and equity rationing developed here is that it describes many aspects of observed aggregate behavior, which are difficult to account for in terms of traditional macroeconomic models, remarkably accurately. At the same time, it embodies realistic microeconomic assumptions about information availability which produces highly reasonable microeconomic descriptions of firm and lending institution behavior.

\footnotetext{
37 If leaming by doing is incorporated into the model, different steady-states correspond to different growth rates as well as different levels and temporary deviations from steady-state have persistent effects on the level of output (see Greenwald and Sigliz [1989]).
} 


\section{Appendix}

This appendix describes the structure of information which underlies the microeconomic description of firm level behavior in Section I of this paper. In doing so, it will be useful to begin with the model of the text altered only slightly to include an additive productivity factor, $\theta_{l}$, which is unobservable to outside investors but known with certainty by a firm's managers so that the profits of the firm are

$$
\pi_{1}=p_{1} q_{1}-\left(1+r_{1}\right) \bar{b}_{1}+\theta_{1}
$$

Substitution from the definition of $\bar{b}_{b}$, and normalization so that $\mathcal{l}_{1}$, output per unit of labor, is one, yield

$$
\pi_{1}=\left(p_{1}-\left(1+r_{1}\right) w_{1}\right) q_{1}+\left(1+r_{1}\right) a_{1-1}+\theta_{1}
$$

where $p_{t}$ is the price at which goods are sold at the end of period $t, w_{t}$ is the wage level, $q_{t}$ is output (investment) in period $t, r_{t}$ is the return to lenders and $a_{t-1}$ is the equity funds which the firm inherits from period $t-1$. At the beginning of each period, each firm receives an independent $\theta_{1}$ draw from a distribution which is the same for all firms. ${ }^{38}$ This distribution has $E\left[\theta_{t}\right]=0$ and a range $\left[\theta_{a}, \theta_{b}\right]$. At the beginning of a period a firm knows $w_{t}, q_{t}, a_{t-1}, r_{t}$ and $\theta_{1}$ with certainty. It also knows the distribution of $p_{t}$ but not the particular realized value of $p_{t}$, which materializes only the end of the period.

At the beginning of period $t$, neither $q_{t}$ nor $\theta_{t}$ is observable to outside investors. We will also assume for the moment that lending to firms is done by banks who have access to confidential firm information (i.e., they observe $\theta_{1}$ and $q_{1}$ ), but are constrained not to reveal that

38 This restriction is of no practical significance since different $\theta$ distributions would correspond wo observationally different classes of firms and we need only replicate the analysis for each such class. 
information either by revealing borrowing levels, $\bar{b}_{z}$, or by acting upon it (i.e., by purchasing the stock of a firm in the open market). Thus only $a_{t-1}$ for each firm is observable to outside (i.e., non-bank) investors at the beginning of period $t$.

We assume that financial contracts are limited to either (1) debr contracts, which provide a fixed return, $r_{t}$, if a firm is solvent or, in the event of insolvency, all the assets of the firm, or (2) equity contracts which provide a fixed fraction of the firm's net wont if the firm is solvent and nothing otherwise. In practice, under equity contracts shareowners receive their returns through dividends. We will assume that loans are made by banks, which are owned, in tum, by households and that equity is held directly by households (i.e., Glass-Steagle like restraints restrict bank ownership of common stock). We will also assume initially that all investors are risk neutral and require an expected rate of $\bar{r}_{t}$ on their investments.

Under these circumstances, the equation determining the level of $r_{t}$, the contractual rate of retum on loans, directly determines the probability that a firm goes bankrupt (i.e., $\pi_{t} \leqq 0$ ). From the definition of $\pi_{t}$, bankruptcy implies that

$$
p_{i}<\left(1+r_{t}\right) w_{t}-\left[\frac{\left(1+r_{t}\right) a_{t-1}+\theta_{t}}{q_{t}}\right] \equiv \bar{u}_{z}
$$

where, by definition, $\bar{u}_{t}$ is the price realization below which firms go bankrupt. The expected total retum to investors is, therefore,

$$
\bar{b}_{t} E\left(1+r_{t}\right)=\left(\bar{u}_{t} \cdot q_{t}+\theta_{t}\right)\left(1-F\left(\bar{u}_{t}\right)\right)+\int_{0}^{\bar{u}_{t}}\left(q_{t} p_{t}+\theta_{t}\right) d F\left(p_{t}\right)
$$

since at prices above $\bar{u}_{t}$, lenders receive $\bar{u}_{t}$ per unit of output plus $\theta_{t}$ and, at prices below $\bar{u}_{t}$. lenders as residual claimants receive the entire $p_{t}$ per unit of output plus $\theta_{t}$ again. The level of $r_{t}$, and hence $\bar{u}_{t}$, is then set so that this expected return is equal to $\left(1+\bar{r}_{t}\right) \bar{b}_{t}$. Thus, substitution 
for $\bar{b}_{t}$ and rearrangement of terms yields

$$
\left(1+\bar{r}_{t}\right)\left[w_{t}-\frac{a_{t-1}+\theta_{t} /\left(1+\bar{r}_{t}\right)}{q_{t}}\right]=\bar{u}_{t}\left(1-F\left(\bar{u}_{t}\right)\right)+\int_{0}^{\bar{u}_{1}} p_{t} d F .
$$

which is just the equation of the text modified by the inclusion of the $\theta_{t}$ factor (which is observed by bank lenders).

Expected profits are also a simple extension of those in the text. In particular

$$
E\left(\pi_{t}\right)=\left(1-\left(1+\bar{r}_{t}\right) w_{t}\right) q_{t}+\left(1+\bar{r}_{t}\right)\left[a_{t-1}+\frac{\theta_{t}}{1+\bar{r}_{t}}\right] .
$$

Thus, in both instances (expected profits and the definition of $\bar{u}_{t}$ ), the effect of the additive productivity factor, $\theta_{t}$, is to replace $a_{t-1}$ by $a_{t-1}+\theta_{t} /\left(1+\bar{r}_{t}\right)$, and the output function of the firm can be written

$$
q_{t}=h\left(w_{t}, \bar{r}_{t}, \sigma_{t}\right)\left[a_{t-1}+\frac{\theta_{t}}{1+\bar{r}_{t}}\right] \text {, }
$$

where the function $h$ is exactly that of the text. ${ }^{39}$ If, therefore, we define

$$
z_{t-1} \equiv a_{t-1}+\frac{\theta_{t}}{1+\bar{r}_{t}}
$$

then the analysis can proceed directly in terms of $z_{t-1}$ instead of $a_{t-1}$. Since $q_{t}$ is linear in $z_{t}$ and $\bar{u}_{t}$ is a function of the ratio of $q_{t}$ and $z_{t}, \bar{u}_{t}$ is independent of $z_{t}$. Thus, the objective function of firms,

$$
\left(1-\left(1+\bar{r}_{1}\right) w_{t}\right) q_{t}+\left(1+\bar{r}_{1}\right) z_{t}-c q_{t} F\left(\bar{u}_{t}\right)
$$

\footnotetext{
39 The use of a more realistic multiplicative productivity factor would merely complicate the analysis without altering its basic implications.
} 
is linear in $z_{1}$ and the end of period valuation function for the multiperiod problem is linear in end of period equity, as are future expected profits (and their discounted value). The expected end-of-period market value of the firm is, therefore,

$$
E\left[V_{l}\right]=k E\left[z_{t+1}\right]=k E\left[a_{t+1}\right]=k^{\prime} z_{t}
$$

where $k^{\prime}$ and $k$ will depend on $w_{t}, \bar{r}_{1}, \sigma_{t}$ and their future expected values, and the second equality follows from the fact that $E\left[\theta_{1}\right]=0$, ex ante, for each $t$.

$\mathrm{N} r w$ consider a decision to raise an amount of equity, $e_{0}$. The share of the firm retained by the original shareholders depends on the market value of the firm when it decides to issue equity, $V_{\alpha}$, where

$$
V_{\alpha}=\left(\frac{1}{1+\bar{r}_{1}}\right) E\left[V_{1}\right]=k^{\prime} E\left[z_{l}\right]\left[\frac{1}{1+\bar{r}_{1}}\right] \text {. }
$$

where the expectations are now taken conditional on the information available to outside equity investors. Thus

$$
E\left[z_{1}\right]=a_{t-1}+\frac{E\left[\theta_{t} / \text { equity issued }\right]}{1+\bar{r}_{t}}
$$

The share of the firm sold to new shareholders is

$$
s=\frac{e_{0}}{e_{0}+V_{\alpha}}
$$

The cost of this equity sale from the perspective of the firm's inside managers is

$$
s \cdot k^{\prime}\left(z_{t}+e_{0}\right)=s k^{\prime}\left[a_{t-1}+e_{0}+\frac{\theta_{t}}{1+\bar{r}_{1}}\right]
$$

since they observe $\theta_{t}$. Since the new equity simply increases $a_{t-1}$, the value of the equity issue, $e_{o}$, is $k^{\prime} \cdot e_{o}$. Thus, the condition that firms issue equity is simply 


$$
e_{0} k^{\prime}\left[a_{t-1}+e_{0}+\frac{\theta_{t}}{\left(1+\bar{r}_{t}\right)}\right] \leqq\left(e_{0}+V_{\alpha}\right) \cdot k^{\prime} e_{0}
$$

or, after rearranging terms,

$$
\theta_{t} \leqq\left(k^{\prime}-1\right) a_{t-1}\left(1+\bar{r}_{t}\right)+k^{\prime} E[\theta / \text { equity issued }] \text {. }
$$

With no impediments to issuing equity, $k^{\prime}$ is equal to one $e^{40}$ and, the equity issue condition becomes

$$
\theta_{1} \leqq E[\theta / \text { equity issued }] \text {. }
$$

This condition implies, in tum, that no equity will be issued. The expectation of $\theta_{\text {, for equity }}$ issuers would be derived only from those with $\theta$, less than that expectation (i.e., those who issue equity according to equation (A-2) above) and this can only $\propto$ ccur at $\theta_{a}$, the lower limit of the $\theta$ distribution, where essentially no one issues equity. Thus, no equilibrium without equity issue restrictions is compatible with the information structure assumed here.

However, an equilibrium with such restriction, and consequently $k^{\prime}>1$, may exist. In that case, it is still firms for which $\theta_{t}$ is less than or equal to some threshold who issue equity (see equation (A-1)) and, in consequence,

$$
E[\theta / \text { equity issued }]<E[\theta / \text { no equity issued }] .
$$

Thus, firms announcing equity issues will face an immediate decline in current market value. If current, as well as end-of-period market value enters a firm's objective function, ${ }^{41}$ this will in

\footnotetext{
40 In general $k^{\prime}$ exceeds one, because without being able to issue unlimited amouns of equity, positive bankouplcy risk ensures that $\left(1+r_{l}\right) w_{l}<1$ and firms make positive profis per unit of outpul Since equity increases output, it earns these positive profits in addition to the normal return $\left(1+r_{1}\right)$.

41 Such a situation will arise if firms serve existing shareholders and existing shareholders sell a fraction of their current holdings in the beginning of each period (after equity issues have been announced). An over-lapping generations model in which current shareholders are older households consuming wealth at a fixed rate will give rise w such a situation.
} 
turn represent an additional fixed cost of issuing equity and a further deterrent to doing so. In practice, therefore, asymmetric information concerning firm prospects (i.e., $\theta_{l}$ ) between managers and outside investors may well restrict equity issues to a small number of firms and an insignificant amount of funds, as appears to be the case in practice. ${ }^{42}$ This is the underlying rationale for the equity issue constraint.

In relaxing the informational assumptions described above, the obvious place to begin is with the assumptions of well-informed bank lenders. If banks cannot distinguish among potential borrowers (i.e. they cannot observe $q_{1}$ or $\theta_{l}$ ), then the contractual rate of interest $r_{l}$ must be set at the same level for all firms. Under these circumstances, the analysis must be adjusted slightly but remains fundamentally unchanged. There is an induced tendency for poor (i.e., low $\theta_{8}$ ) firms to borrow more since they have higher default rates and hence lower expected interest costs for any $r_{t}$ than good (i.e., high $\theta_{t}$ ) firms. This does not, however, alter the linearity of the problem in $z$, so that the basic qualitative results of the fully-informed lender case continue to apply (slightly stronger assumptions are needed to ensure that the second order maximum conditions are satisfied).

A further difficulty is raised if lenders are able to infer $\theta_{b}$ from the level of firm borrowing and reveal this information to investors at large. However, in this case, poor firms would have an incentive to increase borrowing (and invest in non-production technologies) to conceal their low $\theta_{l}$ values from the market. At the same time, very poor firms (i.e., those with $z_{l}<0$ ) have an incentive to borrow a great deal (since the probability of bankruptcy declines with output for such firms) so that the need for viable firms to distinguish thernselves from very poor firms

\footnotetext{
12 With decreasing-retums-to-scale, the value of additional equity is also smaller for high $\theta$ than low $\theta$ firms since the extra output made possible by the additional equity is incrementally less valuable at the high $\theta$ firms higher levels of output. See Taggan (1985).
} 
should set an upper limit on borrowing. Thus, if lenders attempted to infer firm quality from borrowing levels, there would be a countervailing tendency for all firms to borrow the same amount and equilibria exist in which borrowing levels are constant across firms and uninformaive. 


\section{BIBLIOGRAPHY}

Abel, A. B. (1980), "Empirical Investment Equations: An Integrative Framework" in On the Stare of Macroeconomics, K. Brunner and A. Melizer, eds., Carnegie-Rochester Conference Series on Public Policy, Vol. 12. pp. 39-91.

Abel, A. B. and Blanchard, O. J. (1986), "The Present Value of Profits and Cyclical Movements in Investments", Econometrica. Vol. 54, pp. 249-274.

Akerlof, G. A. (1984), "Gift Exchange and Efficiency Wage Theory: Four Views", American Economic Review Papers and Proceedings. Vol. 74, pp. 79-83.

Allen, F. (1984), "Reputation and Product Quality", Rand Journal of Economics, Vol. 15, pp. 311-327.

Asquith, P. and Mullins, D. (1986). "Equity Issues and Stock Price Dilution", Journal of Finan. cial Economics, Vol. 13. pp. 296-320.

Bernanke, B. and Gerler, M. (1989), "Agency Costs, Net Worth and Business Fluctuations", American Economic Review, Vol. 79, pp. 14-31.

Bulow, J. I. and Summers, L. H. (1985), "A Theory of Dual Labor Markets with Applications to Industrial Policy, Discrimination and Keynesian Unemployment", NBER Working Paper No. 1666 (July, 1985), Cambridge. MA.

Diamond, P. A. (1982), "Aggregate Demand Management in a Search Equilibrium", Journal of Political Economy, Vol. 90, pp. 881-894.

Eisner, R. (1967), "A Permanent Income Theory for Investment: Some Empirical Explorations". American Economic Review, Vol. 57. pp. 363-390. 
Greenwald, B., Kohn, M. and Stiglitz, J. E. (1989), "Financial Market Imperfections and Productivity Growth", Journal of Economic Behavior and Organization, (Forthcoming).

Greenwald, B. and Stiglitz, J. E. (1986), "Information, Finance Constraints and Business Fluctuations", NBER Working Paper, June, 1986, Cambridge, MA.

Greenwald, B. and Stigliz, J. E. (1987), "Imperfect Information, Credit Markets and Unemployment", European Economic Review, Vol. 31, pp. 223-230.

Greenwald, B. and Stigliz, J. E. (1988), "Money, Imperfect Information and Economic Fluctuations", in M. Kohn and S. C. Tsiang, eds., Expectations and Macroeconomics., Oxford Univ. Press, Oxford.

Greenwald, B. and Stiglitz, J. E. (1989), "Toward a Theory of Rigidities", American Economic Review, Vol. 79, No. 2, pp. 364-369.

Greenwald, B., Stiglitz, J. E., and Weiss, A. M. (1984), "Informational Imperfections in Capital Markets and Macroeconomic Fluctuations", American Economic Review, Papers and Proceedings, Vol. 74, pp. 194-199.

Hubbard, G., Fazzari, S. and Petersen, G. (1988), "Financing Constraints and Corporate Investment", Brookings Papers and Economic Activity, No. 1, pp. 141-206.

Jorgensen, D. W. (1963), "Capital Theory and Investment Behavior", American Economic Review, Papers and Proceedings, Vol. 53, pp. 247-59.

Lintner, J. (1971), "Corporate Finance: Risk and Investment" in Determinants of Investment Behavior, R. Ferber, ed., NBER, NY.

Lucas, R. E. (1979), "An Equilibrium Model of the Business Cycle", Journal of Political Economy, Vol. 83. pp. 1113-1144. 
Myers, S. C. and Majluf, N. S. (1984), "Corporate Financing and Investment Decisions When Firms Have Information That Investors Do Not", Journal of Financial Economics, Vol. 11, pp. 187-221.

Phelps, E. S. and Winter, S. G. (1970), "Optimal Price Policy Under Atomistic Competition" in E. S. Phelps, ed. Microeconomic Foundations of Employmens and Inflation Theory, New York, W. W. Norton and Co.

Poterba, J. and Summers, L. (1988), "Mean Reversion in Stock Prices", Journal of Financial Economics, Vol. 22, pp. 27-59.

Salop, J. and Salop, S. (1976), "Self-Selection and Tumover in the Labor Market", Quarterly Journal of Economics, Vol. 90, pp. 619-627.

Shapiro, C. and Stiglitz, J. E. (1984), "Equilibrium Unemployment as a Worker Discipline Device", American Economic Review, Vol. 74, pp. 433-44.

Stiglitz. J. E. (1974), "Alternative Theories of Wage Determination and Unemployment in L.D.C.s: The Labor Tumover Model", Quarterly Journal of Economics, Vol. 88, pp. 194227.

Stiglizz, J. E. (1976). "The Efficiency Wage Hypothesis, Surplus Labour and the Distribution of Income in L.D.C.s", Oxford Economic Papers, Vol. 28, pp. 185-207.

Stiglitz, J. E. (1982), "Altemative Theories of Wage Determination and Unemployment: The Efficiency Wage Model", in Modern Developments in Public Finance: Essays in Honor of Arnold Harberger, M. Boskin, ed., Basil Blackwell, Oxford.

Stiglitz. J. E. (1987), "The Causes and Consequences of the Dependence of Quality on Price". Journal of Economic Literature, Vol. 25, pp. 1-48. 
Sriglitz, J. E and Weiss, A. M. (1981), "Credit Rationing in Markets With Imperfect Information", American Economic Review, Vol. 71, pp. 393-440.

Taggar, R. (1985), "Secular Patterns in the Financing of U.S. Corporations", in Corporate Capital Structures in the United States, B. Friedman, ed., NBER-Univ. of Chicago Press, Chicago.

Weiss, A. M. (1980), "Job Queues and Lay-offs in Labor Markets With Flexible Wages", Journal of Political Economy, Vol. 88, pp. 526-38.

Woodfond, M. (1986), "Expectations, Finance and Aggregate Instability", in Expectations and Macroeconomics, M. Kohn and S. C. Tsiang, eds., Oxford Univ. Press, Oxford.

Yellen, J. (1984), "Efficiency Wage Models of Unemployment". American Economic Review, Papers and Proceedings, Vol. 74, gp. 200-05.

Zamowitz, V. (1985), "Recent Work on Business Cycles in Historical Perspective: A Review of Theories and Evidence", Journal of Economic Literature, Vol. 23, pp. 523-80. 
</ref_section> 


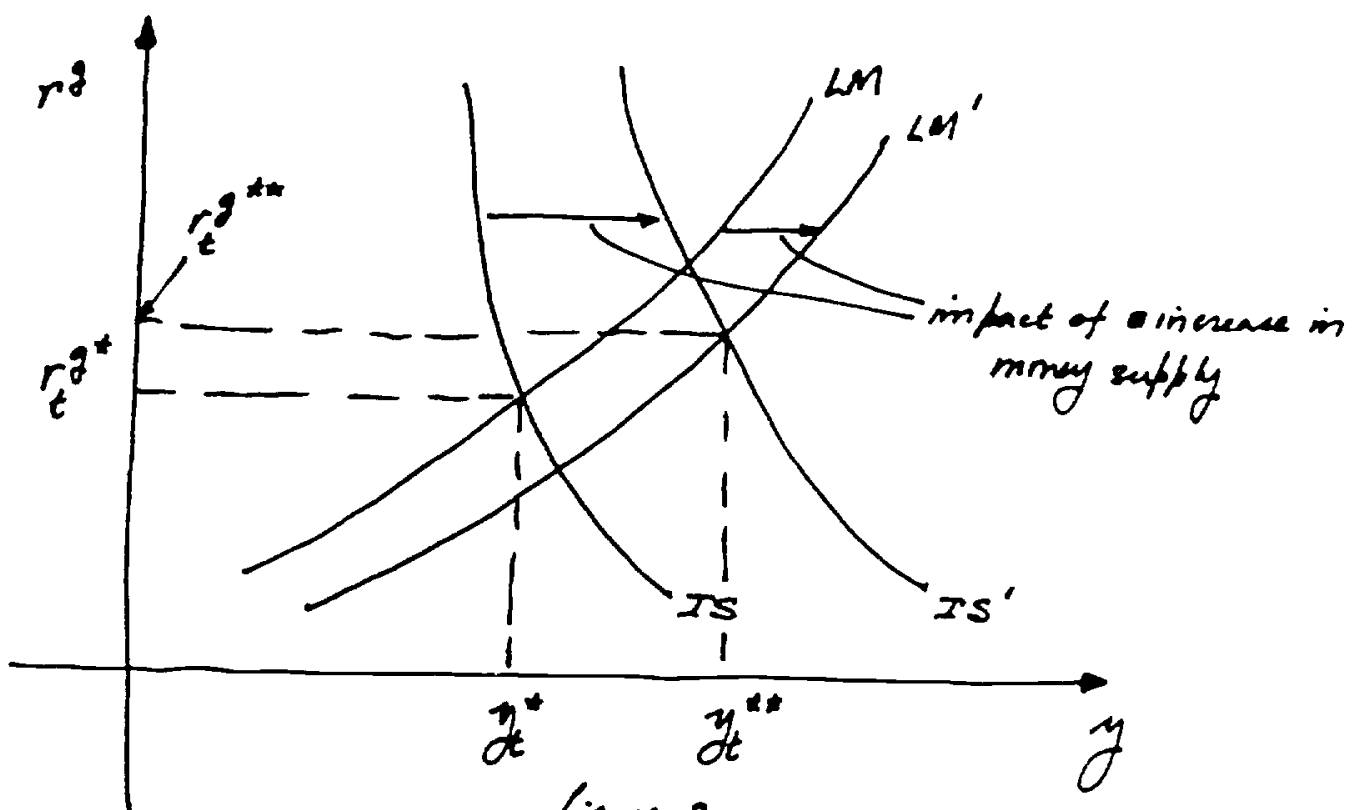

figme 2

Mauseconmic Equilibrium

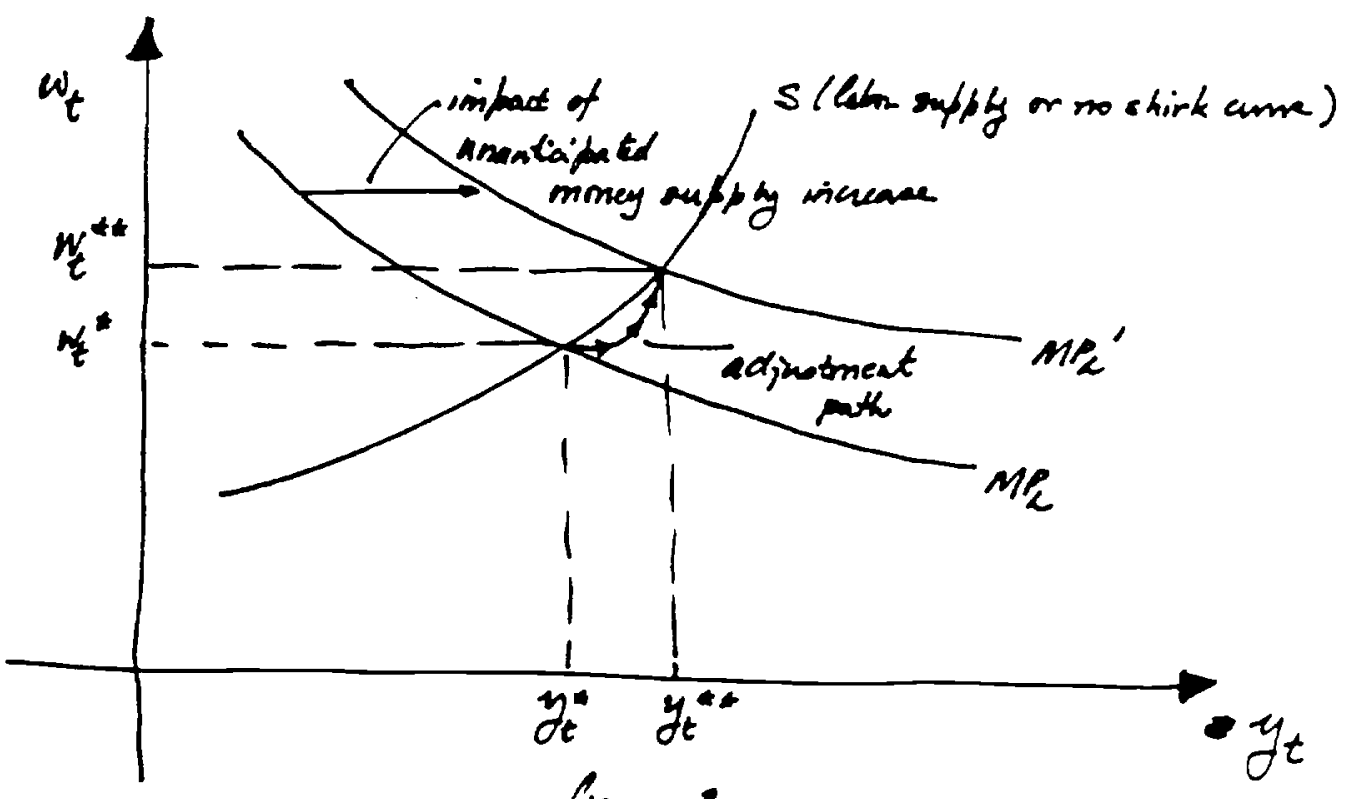

figure 3

Lober Masket Equilibrium 

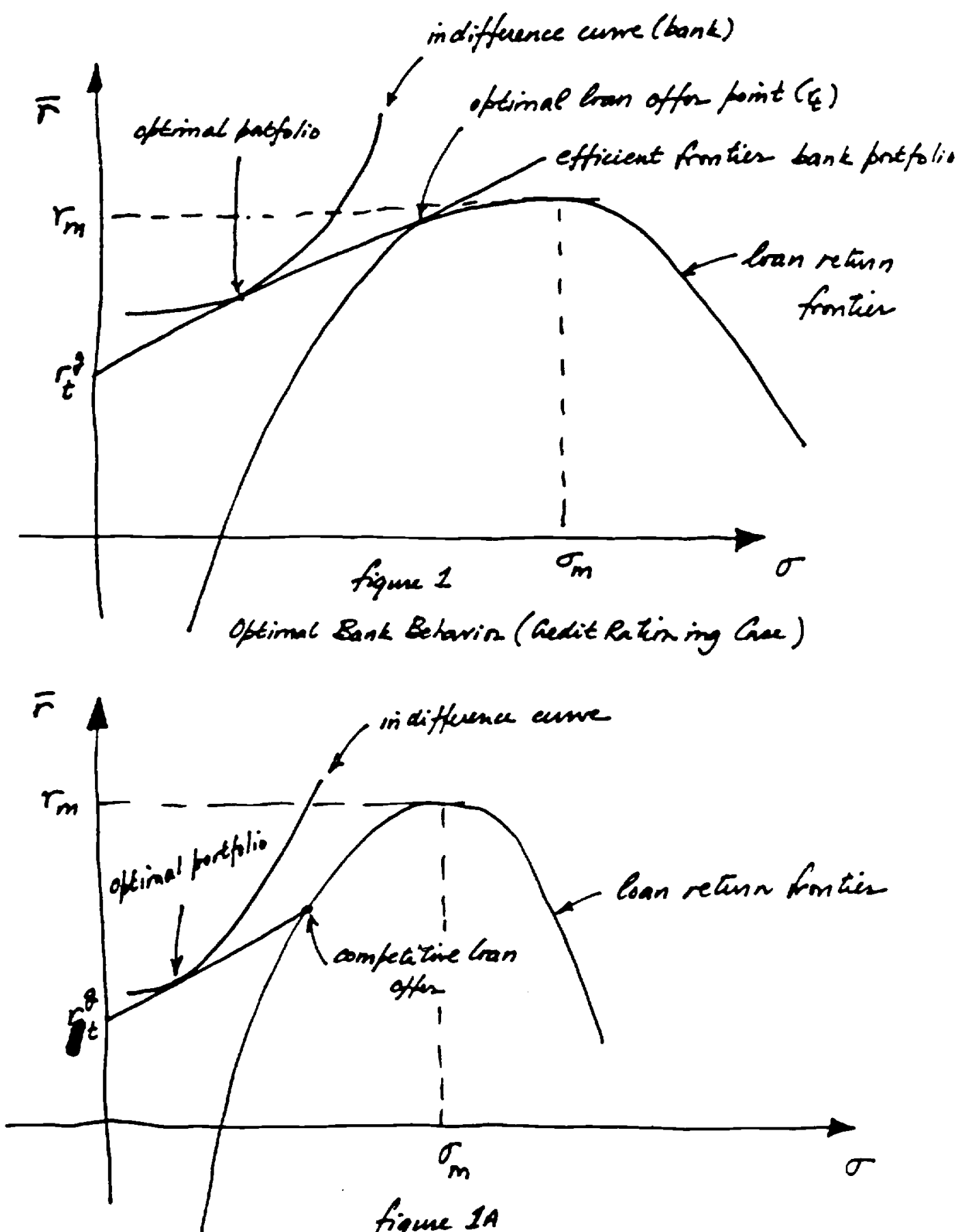

fique $1 A$

Optimal sonk Bcharion (No Ratining Case) 